\title{
Postclassicism, Disturbed Philology, and Kleist’s Fencing Bear
}

\author{
Constanze Güthenke, Oxford University
}

Literary historiography has worried how to place Kleist on the map of the overlapping spheres of (German) Classicism and Romanticism, and while he might be called a 'classic of modernity' in his own right, he may be best classified as, if anything, untimely. ${ }^{1}$ The contemporary reception of his work and persona was conflicted, too, exemplified in Goethe's puzzlement at his play Penthesilea, a pronouncement that has assumed its own canonical place in evaluations of Kleist. ${ }^{2}$ His engagement with classicisms of various kinds is obvious: the Marionettentheater essay is on some level a postclassical response to Schiller’s essay 'Über Anmut und Würde’ (1793) - as much as to Schiller's other essays on aesthetic education and self-consciousness - and hence to Weimar classicism and its relationship with ancient drama more generally. Likewise, some of his dramatic works make classical themes and motives deliberately post- or paraclassical, such as the tragicomic aspects of Der Zerbrochene Krug with regard to Sophocles' Oedipus, or Amphitryon in relation to Euripides and Plautus, or, of course, Penthesilea, with its dramatization of erotic and linguistic violence that culminates in Penthesilea's dismemberment of Achilles.

This article, written from the perspective of a scholar who is a Classicist and a Germanist both, suggests a reading of Kleist’s ‘Über das Marionettentheater’ (1810), a text with a stereoscopic vision of gracefulness and self-consciousness, and a relentless externalization of its own mechanisms, as a postclassicist text: that is to say as a text that reflects and interrogates the relationship with classical materials and a

\footnotetext{
${ }^{1}$ See, for example, Lubkoll and Oesterle (2011), especially the introduction by Lubkoll, Oesterle, and Waldow, pp. 7-19, with extensive bibliography; also Vosskamp (2014), on Kleist's exposure of the structural interdependence of the classical and anticlassical.

${ }^{2}$ In Goethe's letter to Kleist in February 1808, quoted in Sembdner (1996: 199-200), nr. 224. Though see Martin (2014), with further literature, on Kleist's relation with Weimar classicism in general and Goethe in particular.
} 
classicist aesthetic; ${ }^{3}$ but also, more importantly, as a text that is - in its exposure of the precariousness of underlying structures - instructive for scholars examining the culture of classical education and the disciplines of knowing, interpreting, and reading around 1800. For current Classicists, this means reading Kleist as a disruptive guide to emblematic tropes of disciplinary enquiry and pedagogy, especially those glossed on the Platonic desire for knowledge. For Germanists, this is a reminder that the structures of artistic and literary classicism around 1800 are tightly bound up with the structures of classical knowledge and its increasingly professionalized practices, especially in light of their emphasis on pedagogy, understanding, and Bildung.

'Über das Marionettentheater', Kleist's hard-to-define text that was published in four installments in his co-edited journal Berliner Abendblätter in December 1810, is not primarily about classical texts and precedents, but it is, among other things, about classicism as an aesthetic and pedagogical programme and about the epistemological challenges that are activated in the use of classicizing language, examples, and art forms - languages, examples, and forms that were also inevitably a part of the social, cultural, and institutional environment Kleist inhabited. The narrative is told by an unnamed first-person speaker who, in medias res, recounts a conversation he had at a semi-concrete time and place (in winter of 1801 in M--), in a public park, with a Herr C., a successful and admired professional dancer. It is clear that calling 'Über das Marionettentheater' a dialogue is not a straightforward proposition, ${ }^{4}$ and that, even if there are dialogic elements, they may, as Hilda Brown cautioned, have more to do with Diderot than Plato. ${ }^{5}$ And yet, a reminiscence of the morphology of Platonic dialogue suggests itself already in the complex framing: its unapologetic immediate

\footnotetext{
${ }^{3}$ For postclassicism as a concept used by some classicists to expand the structures of their disciplinary assumptions at the intersection of traditional philology, social and cultural theory, and classical reception studies, see the ongoing project sketched out at www.postclassicisms.org.

${ }^{4}$ Figal (2014: 88), for example, insist that ‘narrative’ (Erzählung) more than any other term fits the bill.

${ }^{5}$ Brown (1988: 82). Though it is exactly the triangulated, indirect, subterranean, and multiform pathways and inflections of classical models, tropes, and genres that scholars of Classical Reception have been wanting to take seriously, engaging with a long and wide network that is no longer interested in either straight linearity or neat genealogies.
} 
beginning, for instance, evokes simultaneously the outdoor setting of Plato’s Phaedrus, and the market place as Socrates' habitat for striking up conversations. ${ }^{6}$

The narrator claims to have observed Herr C. some time before when they both watched a puppet show, and the conversation begins apropos this popular, common form of entertainment. The in medias res encounter between two speakers, building its initial momentum by referring back to an earlier encounter, is also not unlike the nested narrative of the opening of Plato's Symposium: here the narrator has been asked to recount a story he has told before about his presence at the symposium in question several years before, which itself was a drinking party the night after the party celebrating a dramatic victory, thus creating multiple, stacked frames of belatedness that involve earlier artistic performances as much as personal recollections, just as they do for the speakers in Kleist's text.

Herr C., the professional practitioner of a high art form, opens his response by expressing his appreciation of the low genre of the marionettes. The counter-intuitive argument as an opening gambit is not unlike Socrates' first speech in Phaedrus, who there explores an argument for the superior value of a non-reciprocated desire (eros). ${ }^{7}$ Herr C. admits to his fascination with the puppets and the pleasure he takes in them, and he argues for his belief in their exquisite, inanimate gracefulness, which itself ought to be a model for human dancers to learn from. Again, if we think about the Platonic-dialogic model, the text instantly highlights and combines the spheres of

\footnotetext{
${ }^{6}$ De Man (1984) already insisted that the essay is best read as a sequence of scenes of instruction. Földenyi (2001) goes further and argues that the Marionettentheater essay presents a pedagogical scene with specific Platonic-dialogic echoes; see also Földényi (1999: 179, 'Grazie'), in his conceptual dictionary of Kleistian key-words, for an association of Herr C. with Socrates and the internal narrator as a Phaedrus figure. Weigel (1988: $278 \mathrm{n}$. 59) points out that the methodological reflections that Schleiermacher articulates in his introduction to the first volume of translations of Plato's dialogues in 1804, 'wirkt bis in Einzelheiten wie ein Vorbild für Kleists erzählten Dialog Über das Marionettentheater'.

${ }^{7}$ Phaedrus 237b-241d. Socrates here puts forward a deliberately provocative argument that in the expected pederastic relationship between an active, older lover (erastes) and a passive, younger beloved (eromenos), it is not the pursued beloved who ought to profess distance and resistance, but the actively seeking older lover instead. This Socratic provocation, which he later retracts, argues for the benefits the beloved receives from entering into an erotic relationship with a professed non-lover as opposed to an ardent lover, thus already disturbing any clear binary of active and passive.
} 
desire and pedagogy: this is not simply about the pleasure of watching the puppets but about the consequences for dancers in training. The puppets' graceful movements are the result of self-completing mechanical sequences, but also of the confidence and skill of the puppeteer, who stimulates the centre of gravity (Schwerpunkt) in the puppet body. It is in fact the puppets' perfect passivity that allows the mechanical forces to create such grace: a form of activation that is both utterly simple, even pedestrian, and utterly mysterious. ${ }^{8}$ Does the puppeteer need to be an accomplished dancer himself, so as to have a concept of dance? In any case, thus Herr C., the business of the puppeteer cannot do without feeling (Empfindung). The line followed by the inanimate centre of gravity is 'der Weg der Seele des Tänzers (Kleist's emphasis)', and it is achieved when the handler himself enters into the centre of gravity ('dass sich der Maschinist in den Schwerpunkt der Marionette versetzt, d.h. mit andern Worten, tanzt', 557). ${ }^{9}$ Contrary to the speaker's initial assumption that the puppeteer is a mere mechanic, engaged in something that is geistlos, the puppeteer is an analogue - whose fingers match the movement of the marionettes, linked in a sequence of algorithms.

Herr C. next imagines an ideal puppet that, if manufactured for him, would achieve the highest degree of gracefulness: it would be built on the model of the prosthetic limbs developed by English artisans in aid of those unfortunates who had lost a leg or two (a good reminder that this is not only a classical and post-classical world, but also a war and post-war one, during and after the Napoleonic campaigns). The advantages of such a marionette would be its utter lack of Ziererei - of hesitation, shame, resistance, or any other disconnect of the soul from its centre of gravity (559). Herr C.'s example are two dancers, P. and F., whose recent classical performances of Daphne chased by Apollo, and of Paris awarding the apple of judgment to Aphrodite, were marred by such sudden disconnects, by sudden intrusions of consciousness. Again, we have professional practitioners of a classicizing art form. For the modern

\footnotetext{
${ }^{8}$ The question that is raised here about the opposition of conscious and unconscious skill in relation to technique is one that is also central to another of Plato's dialogues, the Ion, where it is discussed in the case of the inspired performer of Homeric poetry. ${ }^{9}$ The text throughout is quoted after the edition of his collected works in four volumes by Barth et al. (1987-1997), abbreviated as SWB. Page numbers in brackets refer to the printing of the text in volume 3, pp. 555-563; translations, unless otherwise stated, are my own.
} 
dancer in the act of re-performing antiquity, the gates of paradise are closed, the apple has been eaten (notice, apropos the image of the apple, the transition from Paris' pagan judgment to the Christian fall of man), 'the cherub is behind us' (559). The lesson of Genesis 3 - concerned as it is with 'this first period of all human Bildung' (560) - is that only the lifeless puppet or (a) god can achieve perfect order and gracefulness. In response, the narrator suggests another case study of Bildung, ${ }^{10}$ experienced when he himself a few years ago had been bathing with a youth exceptional in his physical gracefulness: 'Ich badete mich, erzählte ich, vor etwas drei Jahren mit einem jungen Mann, über dessen Bildung damals eine wunderbare Anmut verbreitet war' (560). Kleist here subtly fuses - or collapses - the multiple meanings of Bildung: as personal, spiritual development, as much as the concrete human form and shape (over which gracefulness is poured), merging again education and aesthetic, erotic appeal. The young man unselfconsciously repeated the pose of the Dornauszieher, the Hellenistic statue of a boy removing a thorn from his foot, which the narrator and his charge had happened to have seen just a little earlier in Paris: 'es traf sich, dass wir gerade kurz zuvor in Paris den Jüngling gesehen hatten, der sich einen Splitter aus dem Fusse zieht' (561) - another instance of belatedness and thus intimation of self-consciousness already, and also another instance of the calculated confusion of inanimate statue and living body, since only after this sentence is it made explicit that the Parisian Jüngling is a statue whose casts were popular all over Europe. And predictably, once the boy catches in a mirror his own image and the eye of the narrator watching him at the same time, he is, try as he might, no longer able to reproduce the pose. Like a Narcissus, he remains transfixed for an unspecified time in front of what Kleist and the narrator imagine as a world of mirrors, his former Anmut lost for good in the eyes of himself as well as his observers and admirers. That the anecdote is rounded off with the comment 'Noch jetzt lebt jemand, der ein Zeuge jenes sonderbaren und unglücklichen Vorfalls war, und ihn, Wort für Wort, wie ich ihn erzählt, bestätigen könnte’ (561) is reminiscent of the opening gambit of the Symposium again, the plea to a witness to recount the experience of Socrates and the speeches made at the symposium, word for word.

\footnotetext{
${ }^{10}$ For Kleist's increasingly ambivalent, and eventually abandoned, use of the term Bildung and the stifling sense of the ideal of Bildung as formulated in German idealist Humanism, see also Földényi (1999: 52-60, ‘Bildung’).
} 
Herr C.'s final anecdote, capping the story about the boy in turn again, is another tale of pedagogy and instruction: visiting friends in Russia, he engages in some playful fencing with his host's sons, one of whom has just returned from university (and thus hinting at one further advanced stage of Bildung, compared to that of the boy in the previous scene). Herr C. wins when the young man gets distracted: 'Leidenschaft kam dazu, ihn zu verwirren' - but whose Leidenschaft? That of the young man, tripped up by his own passionate involvement, or that of Herr C., wanting to unsettle him? The syntax is ambiguous. Is this another calculated, deliberately provoked confusion? Again, it is difficult to tell the dancer from the dance, or the fencer from the fencing. The young brothers finally take Herr C. to the stables to show him a domesticated bear, whom their father had raised in the yard: 'den er auf dem Hofe auferziehen liess’ (562) - as opposed to what would be the only slightly different an dem Hofe, 'raised at court', which echoes here too, and which again ironically evokes the sphere of social learning and pedagogy. ${ }^{11}$ With his paws, the bear proves invincible as it parries gracefully every fencing move of Herr C. Though the bear remains an animal in captivity, tied to a stake, its strength lies in the fact that, unlike a fencer, it cannot understand evasion and trickery, it has no self-consciousness and hence cannot be manipulated: 'Aug' in Auge, als ob er meine Seele darin lesen könnte, stand er, die Tatze schlagfertig erhoben, und wenn meine Stöße nicht ernsthaft gemeint waren, so rührte er sich nicht’ (562).

${ }^{11}$ De Man already pointed out how strongly the anecdote of the bear has to do with learning and teaching: 'The scene of instruction which repeats itself on all narrative levels of discourse also becomes, mostly clearly in the third anecdote (that of the bear), a scene of reading. Whatever the bizarre figure of the bear may represent or symbolize, his relationship to C is marked by his apparent ability to read him' (de Man 1984: 270-271, his emphasis). For some other suggestions, and the sheer range of what the 'bizarre figure' of the bear might represent, see, for example, Rushing (1998) (the bear as a figure of irony and fiction, following de Man); Hibberd (2001) (the bear as a political symbol of Berlin and, by extension, Prussia); Platt and Rossomachin (2014) argue for the bear, a popular symbol of Russia, as an indirect attack on the rival dramatist Kotzebue (who in other ways too is implicated in Kleist's critique of current dramatic practice) and his links to Russia; Söffner (2014) discusses the bear and its gestures as an index of fictionality and disruptive embodiment. In the overdetermination of the image, surely those need not be mutually exclusive. As for the bear and pedagogy, there is also the anecdote told in Iamblichus' late antique Life of Pythagoras, of the philosopher taming a bear by convincing it, though talk and caresses, to renounce eating men. Iamblichus' text was popular in the Neoplatonic tradition, including the Renaissance, and available in several editions and translations. The story was also attested in J.J. Brucker's readily available Historia critica philosophiae (1742-44). 
Herr C. concludes, and thus concludes the narrative: as self-consciousness decreases, gracefulness increases. And just so, two intersecting trajectories can drift apart until, bent by time and space, or by mirrors, they converge again. Gracefulness appears most pure in the human body (menschlichen Körperbau) which has either no consciousness (the puppet) or eternal consciousness (a god) - and given that this is stated with continuing reference to the human body, that god must still be imagined in the anthropomorphic shape of the classical sculptures, and the classicizing performances and tableaux vivants mentioned earlier on. And so, asks the narrator, would we have to eat of the tree of knowledge again to return to a state of original innocence? Indeed, runs the Herr C.’s conclusion: ‘das ist das letzte Kapitel von der Geschichte der Welt (563)’

In this web of scenes of lost innocence and unselfconsciousness that interact with images of at best promised, but normally incomplete recurrence and reciprocity, the scene of the boy in the mirror, and especially the scene of the rather outlandish fencing bear who stands 'looking eye to eye, as if he could see into my soul' are suggestive of another Platonic scene of the process of recognition. To describe the interplay of desire (eros) and knowledge, as soul, to know itself, needs to look into another soul, just like an eye that to know itself needs to look into another eye. Here is Plato’s Alcibiades $\mathrm{I}^{12}$

Socrates: Then if an eye is to see itself, it must look at an eye, and at that region of the eye in which the virtue of an eye is found to occur; and this, I presume, is sight.

Alcibiades: That is so.

Socrates: And if the soul too, my dear Alcibiades, is to know herself, she must surely look at a soul, and especially at that region of it in which occurs the virtue of a soulwisdom, and at any other part of a soul which resembles this?

\footnotetext{
${ }^{12}$ Alcibiades I, or Alcibiades maior, stages a dialogue between Socrates and the young Alcibiades, on the theme of what self-knowledge is. While its authorship is disputed, its fit with other Platonic dialogues is close, and the Neoplatonic tradition considered it a seminal dialogue for and within Platonic education. Friedrich Schleiermacher included the Alcibiades in his translation of Plato's works, even though he expressed doubts about its authenticity and quality in his introduction to the work in 1809, in fact setting the tone for a new, and lasting, scholarly depreciation of the dialogue.
} 
Alcibiades: I agree, Socrates. (Alcibiades I 133b, trans. Lamb)

Likewise, in the Phaedrus, eros is seen to flow back and forth from beloved to lover and back to the beloved through the eyes, creating a mirror effect, yet one that remains marked by lack of understanding and insight:

And as this intimacy continues and the lover comes near and touches the beloved in the gymnasia and in their general intercourse, then the fountain of that stream which Zeus, when he was in love with Ganymede, called "desire" flows copiously upon the lover; and some of it flows into him, and some, when he is filled, overflows outside; and just as the wind or an echo rebounds from smooth, hard surfaces and returns whence it came, so the stream of beauty passes back into the beautiful one through the eyes, the natural inlet to the soul, where it reanimates the passages of the feathers, waters them and makes the feathers begin to grow, filling the soul of the loved one with love. So he is in love, but he knows not with whom; he does not understand his own condition and cannot explain it; like one who has caught a disease of the eyes from another, he can give no reason for it; he sees himself in his lover as in a mirror, but is not conscious of the fact (Phaedrus, 255c-d, trans. Fowler).

Kleist re-keys the motif in the transition from the unselfconscious-then-conscious boy and his observer in the second anecdote to the graceful fencer, tutor turned tutee, visà-vis the unselfconscious, humanly trained but essentially still non-human, bear in the third one. Just what is the level of contact and communication between fencer and bear? Is Kleist's remarkable 'as if' (als ob), 'as if he could look into my soul', an expression of affective fallacy, or is it an indictment of it? Is it an acknowledgement of the power of fictionality that itself is part of a classical aesthetic? ${ }^{13}$ And what exactly is the status of the bear? It is not inanimate, but also not fully human, nor fully divine. And yet (or rather, therefore), it is a model of gracefulness, the matching part, found by the one-time dancer-tutor. The description of the moment of insight, the progression through a mirroring of beauty, and at the same time the constant possibility of failure to achieve either closeness or, through closeness, understanding, echoes heavily not only in Plato's Alcibiades as quoted above, but also with the Alcibiades of Plato's Symposium: he is the surprise figure who enters the scene last and late, unbidden and incongruous, in his drunken state full of a dangerous

\footnotetext{
${ }^{13}$ See Pavel (1996). On the important 'as if' in the story of the bear, and the bear's disruptive force, see also Söffner (2014).
} 
unpredictability and vitality (maybe again not unlike the bear), to give a speech that is about the contrast between outer appearance and inner realities - Socrates' as much as, arguably, Alcibiades’ own. ${ }^{14}$

A few more words to situate the Symposium as a dialogue that dramatizes the incompleteness of desire and understanding: it stages a series of speeches, given at a symposium that celebrates a theatrical victory, in praise of the god Eros, which build up to the formulation of how cognition of the (capital-B) Beautiful as an ideal form can be achieved through a sequence of increasing abstraction from the beautiful individual towards shared characteristics of material beauty, to Beauty itself. This path is suggested in the speech of Socrates, though he ostensibly repeats here the teachings he received from Diotima, a Mantinean priestess. This is a dialogue that interweaves and enacts the gaining of knowledge, process, pedagogy, and desire for what is absent as its driving force. It does not close with the ventriloquism of Diotima's speech, though. Instead, it gains a second wind with the sudden arrival and subsequent speech by the gatecrashing, drunken Alcibiades, the unbidden guest and young desirable, whose political star is at the moment of the dialogue's staging still high. Alcibiades follows the rules of the symposium, by offering a praise speech, and yet he twists them, by offering a speech in praise of Socrates, which, in effect, amounts to a eulogy of eros, figured as the philosopher generally and as Socrates in particular. Alcibiades - the beloved (eromenos) conventionally expected to be passive, who has unexpectedly turned lover (erastes) - recounts his active wooing of Socrates that is both uncommon and unsuccessful: once, he recounts, he spent a night approximating to him, trying to embrace him, seeking a physical closeness that remained one-sided, and experiencing a total lack of erotic reciprocity on the part of Socrates. ${ }^{15}$ This is, of course, an inversion of the expected erotic economy and

\footnotetext{
${ }^{14}$ If Kleist's bear is figured as the dangerous animal acting in a pedagogical setting, then it is worth recalling that the figure of Alcibiades himself is in the Greek literary tradition repeatedly associated with the motive of the lion cub raised in the household or city, only to turn murderous and destructive; see Wohl 2002: 145, with reference to Plutarch and, ultimately, Aeschylus. Földényi (1999: 179) suggests associations between the fencing bear and the murderous bear that is, like another raging Penthesilea, in Kleist's Hermannsschlacht - again in an eye-to-eye encounter, followed by an embrace - set by Thusnelda on her suitor.

${ }^{15}$ On the ambivalent, latently (or explicitly) violent nature of the embrace as a theme in Kleist's work, and on the thin line between closeness and murderous passion, see
} 
direction of non-reciprocity. As part of the eulogy of Socrates/Eros, and to frame his own mistaken courting of the philosopher, Alcibiades also famously compares Socrates to an agalma, an ornament or votive, here in the shape of a Silenus: a semidivine figure from the retinue of Dionysus, older, a kind of tutor of the younger satyrs. Alcibiades explores the image of a vessel shaped as Silenus, whose external ugliness hides riches hidden within (which are in fact smaller figurines of gods), though the image of course also underlines the inanimate, yet somehow mobile, statue-like nature of Socrates - another evocative parallel with the mechanical puppets and the centered bodies of 'Über das Marionettentheater' ${ }^{16}$

Alcibiades, self-consciously admitting to his night spent unsuccessfully lying next to Socrates, can on some level be seen as the embodied possibility of a failure of learning and of a failure of teaching - I put the emphasis on 'possibility' since it can be argued that he stands for an affirmation of realism as much as he helps the delineation of idealism - and, after all, he is the first to admit to his lack of success. ${ }^{17}$ On the Socratic learning curve, though, he represents on some level the disconnect in the moment of closeness. His is a late entry, an irritant, a disruptive force, both figuratively and literally, as is, of course, Socrates himself.

Do the echoes of Platonic dialogue in Kleist go beyond a general level towards a more specific focus on human encounters driven by desire for knowledge, and by the

Földényi (1999: 428-429, 'Umarmung’). On the embrace as a marker of past possibility, and yet failure, downfall, and fictionality, compare also Kleist's letter to Ernst von Pfuhl of 7. January 1805, with its explicit evocation of a Hellenic homosocial utopia: 'So umarmen wir uns nicht wiede[r!] So nicht, wenn wir einst, von unserm Sturze erholt, den wovon heilte der Mensch nicht! Einander, auf Krücken, [wie]derbegegnen[.] Damals liebten wir ineinander das Höchste in der Menschheit; den wir liebten die ganze [Aus]bildung unsrer Naturen, ach! in ein paar glücklichen Anlagen, die sich eben entwickelten. Wir empfanden, ich wenigstens, den lieblichen Enthusiasmus der Freundschaft! Du stelltest das Zeitalter der Griechen in meinem Herzen wieder her, ich hätte bei Dir schlafen können, Du lieber Junge; so umarmte Dich meine ganze Seele! $(4,336)$ '. If this suggests the youth of them both, as opposed to the master-pupil relationship of Socrates and Alcibiades who have different ages, a few paragraphs earlier Kleist had asked 'Warum kann ich dich nicht mehr als meinen Meister verehren, o du, den ich immer noch über Alles liebe?' (Kleist's emphasis).

${ }^{16}$ For the structure and implications of Alcibiades likening Socrates to a statue, see, helpfully, Steiner 1996.

${ }^{17}$ See Sheffield 2006 and Nussbaum 1979 for a more positive evaluation of Alcibiades. 
encroachment of the non-human (inanimate, or divine) to test the boundaries of such encounters? The figure of Alcibiades is particularly suggestive in activating many of the neuralgic points of such encounters as they reflect on the possibility and the precariousness or failure of understanding. Whether Kleist had direct reading experience of Plato or not is unclear: it is not unlikely, at least, that Kleist may have encountered Schleiermacher's widely publicized, and reviewed, translations of Plato's works. ${ }^{18}$ In any case, the affinity of Kleist's text with the problems of understanding as they cluster around the figure of Alcibiades in Plato are no less suggestive as a prompt for re-evaluating both the Platonic text and, more importantly here, the use of this motive of encountering and understanding an other as expressed in contemporary programmatic writings regarding classical scholarship and its imagined foundational scenes of pedagogy. Rather than pursue an inquiry into Kleist's sources, then, I suggest a reading of Kleist in light of Platonic materials under a shared frame of pedagogy and its disturbances.

As mentioned before, Laszló Földényi, in a careful reading, has commented on the dialogic and erotic themes of the Marionettentheater essay, putting emphasis on what he calls a 'Drama der gestörten Erotik'. ${ }^{19}$ He rightly highlights the themes of seduction and of deception, and of the desire to make sense. This he sees reflected in the increasingly wide gap of probability in the anecdotes which Herr C. and the narrator trade, and in their striving to make a fulfilling whole that binds them in a mutual, though ironically destabilized desire both to believe and to be believed. It is here that Földényi makes specific reference to the Symposium as a locus classicus for the intertwining of erotic and epistemological desire, but it is possible to explore the dialogues' echoes in the essay even further, and to underline in turn even more the

\footnotetext{
18 The project started as a collaboration with Friedrich Schlegel. Even if there is no direct evidence for Kleist reading Plato in Schleiermacher's or in any other translation, the intellectual and social circles of the two men overlapped. Martyn (2004) reads Schleiermacher's hermeneutics and Kleist's 'Über die allmählige Verfertigung' in parallel (or rather in contrast), yet only with reference to 'understanding' as a common point of triangulation; see also Weigel (1988), as quoted above. The Symposium as an efficacious, even though much more indirect reference point, is also activated in Figal (2014: 98), who in his discussion of Kleist's text integrates thoughts from Paul Valéry's philosophical essay-dialogue 'L'âme et la danse' in which Socrates and Eryximachus (the medical doctor who is also a character in the Symposium) discuss the effect of non-intentional beauty in the art of dance.

${ }^{19}$ Földényi (2011: 146).
} 
elements of a 'disturbed' pedagogy that are as present and efficacious in Kleist's essay as they are in Plato’s Symposium.

In this light, it is possible to integrate even better one of the few examples of a classical scholar referencing Kleist’s ‘Über das Marionettentheater'. Timothy Powers, in a recent reading of Plato's Laws, felt reminded of Kleist's essay - which, in passing, he calls a 'neoplatonic dialogue' - apropos the divine puppets mentioned in a discussion on the theory of the state and of citizenship. Here, Plato's idealized citizenchoristers, that is the citizen taking part in public performances, are imagined as a 'mechanized plaything of the god' (803c) and as manipulated dancing puppets (804a); later on, the notion of control is reprised in the image of a theion thauma, a marvelous or divine artifact that is gracefully controlled by an exterior force, by the golden string of nomos and reason at $644 \mathrm{~d}-645 \mathrm{~b} .{ }^{20}$ What is crucial is that Laws here very specifically debates the education of the citizen - again, therefore, Kleist's essay resonates apropos a pedagogic theme that is easy to overlook if our eye is trained on Kleist's engagement with aesthetic and artistic issues in his description of the puppets alone.

This is true not only of 'Über das Marionettentheater', but allows to integrate a number of Kleist's other essays, that explicitly or implicitly reflect on the dialogical, and on communication and the creation of knowledge. His 'Katechismus der Deutschen' (1809), for example, is a 'pseudo-dialogue' that stages the exchange

\footnotetext{
20 'Let us suppose that each of us living creatures is an ingenious puppet of the gods, whether contrived by way of a toy of theirs or for some serious purpose-for as to that we know nothing; but this we do know, that these inward affections of ours, like sinews or cords, drag us along and, being opposed to each other, pull one against the other to opposite actions; and herein lies the dividing line between goodness and badness. For, as our argument declares, there is one of these pulling forces which every man should always follow and in no way leave hold of, counteracting thereby the pull of the other sinews: it is the leading-string, golden and holy, of "calculation," called the public law of the State; and whereas the other cords are hard and steely and of every possible shape and semblance, this one is flexible and uniform, since it is of gold. With that most excellent leading-string of the law we must needs co-operate always; for since calculation is excellent, but gentle rather than forceful, its leadingstring needs helpers to ensure that the golden kind within us may vanquish the other kinds' (trans. Bury, modified).
} 
between a father and son. ${ }^{21}$ The monologic elements imbalance and disturb any genuine dialogue (arguably, this is not un-Platonic either), when the father insistently reiterates his expectations, allowing only short moments of the son's own voice to be heard. If we combine the aspects of failed citizen education with the aspect of a failed erotics, both articulated through a link with the dialogue form and content, can we then not also speculate about Kleist's essay not only as a 'Drama der gestörten Erotik’, but also as a drama of a disturbed or interrupted classicism and its pedagogy of reading and understanding, a 'Drama der gestörten Philologie’?

For another imagination of disturbance, and specifically the illusion of the (Platonic) eye looking into another eye as an expression of mutual understanding, Kleist's 'Über die allmählige Verfertigung der Gedanken beim Reden’ is instructive. Probably written in 1805-06, this essay in shape of a letter is addressed to his friend Otto Rühle von Lilienstern ('an R. v. L.') and it confronts explicitly the challenge of how to articulate knowledge. While it starts ‘[w]enn du etwas wissen willst und es durch Meditation nicht finden kannst, so rathe ich dir, mein lieber, sinnreicher Freund, mit dem nächsten Bekannten, der dir aufstößt, darüber zu sprechen’ (534), any such pedagogical and epistemological optimism is immediately tempered. ${ }^{22}$ Kleist goes on to reflect on the example of himself discussing mathematics with his sister, and of the anecdote of Molière talking with his servant girl: neither of those interlocutors, he emphasizes, actually know more or know better, nor do they even ask the right questions. In fact, there is no question of actual community, equality, or dialogue. It is not the individuality of the other that is needed, but it is the effect of the mirror, the prompt given by another face that matters:

Es liegt ein sonderbarer Quell der Begeisterung für denjenigen, der spricht, in einem menschlichen Antlitz, das ihm gegenübersteht; und ein Blick, der uns einen halbausgedrückten Gedanken schon als begriffen ankündigt, schenkt uns oft den Ausdruck für die ganze andere Hälfte desselben (536).

Kleist then famously discusses Mirabeau's last speech before the royal assembly and the way in which it provoked the express articulation of radical, revolutionary thinking. Critical readings of this essay have quite rightly explored the underlying

\footnotetext{
${ }^{21}$ Földényi 2011 makes the link to this essay apropos the presence or absence of dialogue in Kleist.

${ }^{22}$ The text is quoted after SWB 3, pp. 534-540.
} 
violence that link political with physical-scientific examples (as in his comparison of the excitation of articulated speech and its subsequent 'cleansing' to the experimental arrangement of a Leiden bottle, a kind of condensator). And yet, what is just as remarkable is the analogous example of gradually articulated speech and a pedagogical situation, to which Kleist returns in a long passage at the end of the essay and which is worth quoting in full:

Wie notwending eine gewisse Erregung des Gemüts ist, auch selbst nur, um Vorstellungen, die wir schon gehabt haben, wieder zu erzeugen, sieht man oft, wenn offene, und unterrichtete Köpfe examiniert werden, und man ihnen ohne vorhergangene Einleitung, Fragen vorlegt, wie diese: was ist der Staat? Oder: was ist das Eigentum? Oder dergleichen. [...] Hier aber, wo diese Vorbereitung des Gemüts gänzlich fehlt, sieht man sie stocken, und nur ein unverständiger Examinator wird daraus schließen daß sie nicht wissen. Denn nicht wir wissen, es ist allererst ein gewisser Zustand unsrer, welcher weiß. Nur ganz gemeine Geister, Leute, die, was der Staat sei, gestern auswendig gelernt, und morgen schon wieder vergessen haben, werden hier mit der Antwort bei der Hand sein. Vielleicht gibt es überhaupt keine schlechtere Gelegenheit, sich von einer vorteilhaften Seite zu zeigen, als gerade ein öffentliches Examen. Abgerechnet, daß es schon widerwärtig und das Zartgefühl verletzend ist, und daß es reizt, sich stetig zu zeigen, wenn solch ein gelehrter Roßkamm uns nach den Kenntnissen sieht, um uns, je nachdem es fünf oder sechs sind, zu kaufen oder wieder abtreten zu lassen: es ist so schwer, auf ein menschliches Gemüt zu spielen und ihm seinen eigentümlichen Laut abzulocken, es verstimmt sich so leicht unter ungeschickten Händen, daß selbst der geübteste Menschenkenner, der in der Hebammenkunst der Gedanken, wie Kant sie nennt, auf das Meisterhafteste bewandert wäre, hier noch, wegen der Unbekanntschaft mit seinem Sechswöchner, Mißgriffe thun könnte. Was übrigens solchen jungen Leuten, auch selbst den unwissendsten noch, in den meisten Fällen ein gutes Zeugnis verschafft, ist der Umstand, dass die Gemüter der Examinatoren, wenn die Prüfung öffentlich geschieht, selbst zu sehr befangen sind, um ein freies Urteil fällen zu können. Denn nicht nur fühlen sie häufig die Unanständigkeit dieses ganzen Verfahrens: man würde sich schon schämen, von jemandem, daß er seine Geldbörse vor uns ausschütte, zu fordern, viel weniger, seine Seele: sondern ihr eigener Verstand muß hier eine Musterung passieren, und sie mögen oft ihrem Gott danken, wenn sie selbst aus dem Examen gehen können, ohne sich Blößen, schmachvoller vielleicht als der, eben von der Universität kommende, Jüngling gegeben zu haben, den sie examinierten (539540).

Unlike with the 'discharging' effect of the condensator, or the catalytic effect of the Assembly, Kleist here elaborates, at notable length, on the halting, failing, pointless dialogue exemplified in the public examination. This is the end of the essay. There is, in the manuscript, a note, in a different hand, claiming 'Die Fortsetzung folgt' (which it did not), but it is evident in the facsimile that this closing paragraph got worked and 
reworked intensely by Kleist. ${ }^{23}$ Aside from his critique of the current system of university education, of interest is also the direct reference he makes to intellectual midwifery, the 'Hebammenkunst der Gedanken'. Kleist has been shown to reference Kant explicitly here, though Kant's usage of the motif is itself, in triangulation, a reflection of the concept as used by Plato. ${ }^{24}$ Reflection on learning, structures of learning, and articulation of thought again.

What we know of Kleist's actual, even though limited, classical education also chimes with his interests in the structures of learning. It is clear from the sources on his early schooling and on his almost three semesters of university study in Frankfurt an der Oder, that he had no instruction in Greek, and only some Latin. ${ }^{25}$ But there is some evidence that the pedagogical theme as such was of personal and scholarly interest to his childhood tutors. Kleist's Hauslehrer, the theologian Christian Ernst Martini, who later became director of the Frankfurter Bürgerschule, was himself trained in the 'Socratic method' by his tutor, J.(Josias) F.C. Löffler, who was a friend and frequent guest of the Kleist family, and had among others also taught the young Humboldt brothers. ${ }^{26}$ Löffler expressed strong admiration for the figure of a rationalist yet charismatic Socrates: something that is in line with eighteenth century reading traditions of Socrates; ${ }^{27}$ but also something that Kleist might reflect himself when he, like his former tutor, in his own early writings refers to Socrates and Jesus in the same breath. ${ }^{28}$ This may be less the ironic, gadfly Socrates of Plato, and more the inspiring, yet genteel Socrates familiar from Xenophon's philosophical and expressly pedagogical writings, especially the Memorabilia, a text which Löffler himself edited, in line with the prevalence of Xenophon as a school author. This does

\footnotetext{
${ }^{23}$ The facsimile is reproduced and transcribed in the edition of Kleist's collected works as the so-called Brandenburger Ausgabe, by R. Reuss und P. Staengele (19882010); here cited from volume II/9, pp. 27-32.

${ }^{24}$ Smith (1995), which deals with the theme of midwifery in the Marquise von O., has traced back the Kantian reference as it appears there (and in the Marionettentheater) not only to Kant's Metaphysics of Morals, but also to his 1803 treatise on pedagogy. ${ }^{25}$ Kleist matriculated there in the autumn of 1799, and abandoned his studies in spring 1801; Heinrich (1983); Loch (2003: 45-51); Blamberger (2011: 51-84). ${ }^{26}$ Loch (2003 17-19).

${ }^{27}$ See, for details, Böhm (1929).

${ }^{28}$ Kleist refers to Socrates and Jesus in his essay 'Aufsatz, den sichern Weg des Glücks zu finden', whose date is insecure but which contains passages that show great overlap with a letter to Martini of March 1799, see SWB 3, 1110.
} 
not preclude Plato at all, but it shows that the association of Socrates and pedagogy was, as a theme, certainly available to Kleist.

It is well known that Kleist's relationship with the spheres of science and scholarship was, especially in its institutionalised form, highly ambivalent. The (long) turn of the century around 1800 is a period of strong and not uncontested institutionalisation, professionalization, and disciplinarization - a background against which Kleist's misgivings appear a timely contribution to the debate. Werner Frick, in a dense and rich essay, has explicated Kleist's associative logic and his methodical approach of what he calls a 'kalkulierte Ent-Disziplinierung und Ent-Spezialisierung des Wissens (1997: 228, his emphasis). He details Kleist’s discontent with a one-sided, singleminded specialist knowledge, formulated in strong images such as that of scholars like caterpillars not seeing the tree they sit on, ${ }^{29}$ or, memorably, that of Isaac Newton who knows in a beautiful décolleté only the mathematical curve, or of the scholar of chemistry acknowledging in a tender kiss only the confluence of gaseous states. ${ }^{30}$ That such an indictment of forms of inquiry is 'probably not accidentally [expressed] in erotic metaphors' (220), ties Kleist's critique of Wissen forward to the link of erotic desire and knowledge he explores ten years later in the Marionettentheater essay. His indictment of 'cyklopische Einseitigkeit', in the same letter as the comments on Newton, ${ }^{31}$ evokes classical themes: in the 'Cyclopean', one-eyed limitation as much as in its opposite, namely encyclopedic breadth, suggestive at a point in time when encyclopedic training was being redefined and reclaimed by classical philology as its professional and pedagogical remit. ${ }^{32}$

Kleist's experimentation with forms of Entdisziplinierung and the de-specialization of knowledge has usually been discussed with reference to his hybrid and disruptive, boundary-breaking intrusion of images and pieces of mathematical, physical, or

29 'Diese Menschen sitzen sämmtlich wie die Raupe auf einem Blatte, jeder glaubt seines sei das Besste, u um den Baum bekümmern sie sich nicht'; letter to his sister Ulrike von Kleist, 5. February 1801, SWB 4, 198.

30 'Ach, mich ekelt vor dieser Einseitigkeit! Ich glaube, dass Newton an dem Busen eines Mädchens nichts anderes sah, als seine krumme Linie, u daß ihm an ihrem Herzen nichts merkwürdig war, als sein Cubikinhalt. Bei den Küssen seines Weibes denkt ein ächter Chemiker nichts, als daß ihr Athem Stickgas u Kohlenstoffgas ist', letter to Adolphine von Werdeck, 28/29. July 1801, SWB 4, 257.

${ }^{31}$ Ibid., p. 257.

${ }^{32}$ See below on Boeckh’s Encyclopädie; also Franzel (2014), with further references. 
architectural knowledge and scientific experimental cultures into his similarly experimental poetics, including the Marionettentheater essay. ${ }^{33}$ That is to say, Kleist's contribution to the debate over the relationship of science and literature is framed mostly with regard to the natural sciences. What if we add to this the presence of classical knowledge, against the background of a discipline that is itself engaged in a complex process of formation and assertion right then? This is where Kleist is himself a good reminder, a Störfaktor, when examining the formation of classical knowledge around 1800. Platonic optimism is deeply inscribed into the programmes of Altertumswissenschaft and Philologie as a master-discipline, and it is a Platonic optimism that, again, borrows strongly from the language familiar from the Symposium. ${ }^{34}$

Here is an example, from August Boeckh’s Encyclopädie und Methodologie der Philologischen Wissenschaften. Boeckh, whose tenure of over fifty years as professor of classical philology at the University of Berlin (1811-1867) shaped the discipline, established the first philological seminar in Berlin and was known well beyond Berlin for his series of introductory lectures he gave from 1809 twenty-six times over fifty years, published posthumously in 1877. Boeckh understands the task of the philologist as that of someone seeking to understand a foreign individuality - in this case that of an ancient culture tout court, glossing philologia as 'Lust zu und an wissenschaftlicher Mittheilung’ (22) - a meaning he takes, with exact reference, from Plato's Phaedrus 336e. ${ }^{35}$ His hermeneutic approach is one of approximation: 'Wenn also die fremde Individualität nie vollständig verstanden werden kann, so kann die Aufgabe der Hermeneutik nur durch unendliche Approximation d.h. durch allmähliche, Punkt für Punkt vorschreitende, aber nie vollendete Annäherung gelöst

\footnotetext{
${ }^{33}$ See, for example, Schmidt (1978); Borgards (2005); the thematic issue 'Kleist und die Naturwissenschaften' in Kleist-Jahrbuch 2005; Specht (2010: 309-410, with extensive bibliography); Lü et al (2012). One exception of a different 'science' that has moved into the ken of scholarly observation of Kleist is the interest in his thinking on law.

${ }^{34}$ For the function of Platonic, and erotic, configurations of pedagogy for classical knowledge and its institutionalized forms, see, for example, Güthenke 2010; Orrells 2011.

${ }^{35}$ All quotations from Boeckh's Encyclopädie come from the version posthumously published in 1877 by Ernst Bratuschek. Bratuschek himself, who heard the lectures late in Boeckh's life, relied for his edition on Boeckh's lecture notes and his own, as well as a strong belief in his own understanding of Boeckh.
} 
werden' (86). This incomplete approach (Annäherung) is compensated for and articulated through the involvement of feeling, which, Boeckh suggests, can sometimes, though rarely, achieve a kind of unexpected, non-rational intimacy:

Für das Gefühl wird jedoch in gewissen Fällen ein vollständiges Verständniß erreicht, und der hermeneutische Künstler wird umso vollkommener sein, je mehr er im Besitz eines solchen den Knoten zerhauenden, aber freilich keiner weiteren Rechenschaft fähigen Gefühls ist. Dies Gefühl ist es, vermöge dessen mit einem Schlage wiedererkannt wird, was ein Anderer erkannt hat, und ohne dasselbe wäre in der That keine Mittheilungsfähigkeit vorhanden. Wenngleich nämlich die Individuen verschieden sind, stimmen sie doch auch wieder in vielen Beziehungen überein; daher kann man eine fremde Individualität bis auf einen gewissen Grad durch Berechnung verstehen, in manchen Äußerungen aber vollständig durch lebendige Anschauung begreifen, die im Gefühl gegeben ist (86).

It is a 'lebendige Anschauung', a vivid intuition that also rests on Empfindung (something Kleist's puppeteer needed), that is communicable only in a flash of insight, and lacks any justification beyond itself - and that sounds just (and deliberately) like Diotima's description of the sudden intuition of the Beautiful itself. Intuition, though, is not predictable, and the residual risk that practice, discipline, and training still cannot guarantee insight is not too far. Boeckh gets some of his Platonic vocabulary for defining the scholar's task from his teacher Friedrich Schleiermacher, whose own influential hermeneutics were implicated in his project of translating and commenting on Plato's works. And it is Schleiermacher, in turn, who addresses headon the ambivalent role of Alcibiades, which takes us back to this figure as an irritant as we see him intimated, at the same time, through a reading of Kleist.

In the introduction to his translation of the Symposium, Schleiermacher treats Alcibiades' account of Socrates as the crowning moment of the dialogue ('die Lobrede des Alkibiades, welche doch offenbar der Gipfel und die Krone des ganzen Gespräches ist'), since it shows us the wholeness of Socrates. This is not a selfevident reading, since one can readily postulate Diotima's speech as the more central one in terms of a Platonic programme. Schleiermacher follows with an analogy between the Platonic reader and the figure of Alcibiades. With considerable slight of hand, he matches Alcibiades' unifying vision of Socrates the true philosopher with 
that of the modern interpreter of Plato who needs to see the whole textual corpus of Plato to make sense of him:

Vielmehr beruht sowohl die Verwandtschaft desselben [i.e the Symposium] mit dem "Phaidon" als auch die Stelle welche wir ihm einräumen auf den Liebesreden nicht minder als auf der Zugabe des Alkibiades, und nur aus dem aufgestellten Gesichtspunkt möchte das Ganze wirklich als Ganzes erscheinen, so dass wir auch behaupten möchten, wer das “Gastmahl” ausser dieser Verbindung und Abzweckung nur für sich, wie es gewöhnlich geschieht betrachtet, der habe, wenigstens was die Komposition betrifft, auch nur gleichsam die äußere, auch schön und zierlich gearbeitete aber doch mutwillige Silenengestalt erblickt, nicht aber das in dieser verschlossene unendlich köstlichere Götterbildnis (285).

And more:

Aber noch auf eine andere merkwürdige Weise findet unsere Anordnung noch im Grossen eine Bestätigung in demjenigen, was Diotima von den allmähligen Fortschritten in den Mysterien der Liebe sagt. Denn dieses Aufsteigen stimmt auf das genaueste zusammen mit der sich weiter entwickelnden philosophischen Darstellung in den Werken des Platon, so dass er hier sich selbst, unwissend vielleicht wie die Schönen oft tun, auf das zierlichste vor uns bespiegelt (285).

In this final turn of the screw, it is the unselfconscious mirror image of a beautiful, attractive, youthful Plato that is revealed by the eye and to the eye of the observer, who, like Alcibiades, is firmly grounded in physical reality, and who, also like Alcibiades, is confronted with the impossibility of knowing Socrates.

In this insistence on approximation, on the striving of the all too human Alcibiades, failure is never far. Kleist's 'Über das Marionettentheater', which appears the year Boeckh is inaugurated in Berlin, is therefore not just a text that can be read in light of classical reflections; it is a text that in turn has the potential to let scholars of the history and theory of classical studies probe further the instabilities inherent in the programmes of classical knowledge such as they were being developed in Germany, with lasting consequences, at that point. What is more, Kleist's insistence on the 'as if' character of all the acts of graceful directing, graceful being, longing observation, and mutual recognition reveals the instability of the assumption that a foreign, past 
culture is or should be accessible like another human individual. His emphasis on the non-human aspects of the other we are engaging with, whether inanimate, sculptural, animal, or divine - together with the subterranean allusions to Alcibiades and Socrates force into light a foundational lack of reciprocity, that can just as easily inhere in the imagination of eye meeting eye.

If this is the benefit Classicists can derive from reading Kleist's text, then for scholars of Kleist and German literature such a reading should confirm that Kleist's 'crisis', which may well be a personal crisis about the possibilities of knowledge and its articulation, is one that corresponds not only to a larger epistemological crisis gradually formulated in various branches of philosophical, aesthetic, and artistic thought, but a crisis of classical knowledge and the interpretation of the classical. Kleist's images and tropes, in this context, are strikingly similar to those relied on by theorists of classical knowledge at the time, and Kleist's radical pressure on them is revealing about their own gestures hinting at a crisis of philology as the understanding of texts, and of pedagogy as its form of communication.

In a letter Kleist writes in the autumn of 1800 from Würzburg to his sister Wilhelmine, Kleist describes a visit to the Julius-Hospital, an institution, an asylum whose philanthropic thrust, a "Product der wärmsten Menschenliebe" is reserved for those marked by their utter helplessness (gänzliche Hülflosigkeit): ${ }^{36}$

Bei den Verrückten [...] kam uns munter u. lustig ein überstudierter Professor entgegen, $\mathrm{u}$ fieng an, uns auf lateinisch zu haranguiren, $\mathrm{u}$ fragte so schnell $\mathrm{u}$ flüchtig $\mathrm{u}$ sprach dabei ein so richtiges, zusammenhangendes Latein, dass wir im Ernste verlegen wurden um die Antwort, wie vor einem gescheuten Manne (118-19).

This scene, which is not without resonance with Kleist's later reflections on examinations in 'Über die allmählige Verfertigung der Gedanken beim Reden’, then immediately turns to the description of a monk:

In einer Celle sass, Schwarz gekleidet, mit einem tiefsinnigen, höchst ernsten u. düstern Blick, ein Mönch. Langsam schlug er die Augen auf uns, u. es schien, als ob er unser Innerstes erwog (119).

\footnotetext{
${ }^{36}$ Letter to Wilhelmine von Zenge of 13.-18. September 1800, SWB, 4, pp. 117-121.
} 
The monk will go on to warn the young men about the dangers of joy; but Kleist's phrasing explicitly suggests the direct glance again of the Platonic gaze, the eye mirroring the self, the direct look of the bear. Kleist and his companion do not know how to respond to him and they remain speechless. Kleist, though, is told of his history and of this he tells his sister in turn: 'Er hatte sich einst auf der Kanzel in einer Predigt versprochen u. glaubte von dieser Zeit an, er habe das Wort Gottes verfälscht' (119).

Of the significant encounters singled out by Kleist, the overly learned, Latinate scholar is followed by the failed interpreter of ancient sacred texts, each of them paying for their mental excesses with their mental wellbeing. Each of them calls forth and is keen to enter into conversation with the visitors. To each of them they respond with embarrassment or unease, in the role of student or disciple. Kleist's scenes, in 'Über das Marionettentheater' and elsewhere, are not merely scenes of disturbed instruction and also of disturbed reading, but they are often scenes of disturbed instruction in reading and understanding, of a disturbed philology.

\section{References}

Kleist's works are cited after the edition Heinrich von Kleist, Sämtliche Werke und Briefe in vier Bänden, ed. I.-M. Barth, K. Müller-Salget, S. Ormanns, H.C. Seeba, 4 vols. Frankfurt/M/: Deutscher Klassiker Verlag (1987-97) [SWB]. Manuscript transcriptions are cited from Heinrich von Kleist, Sämtliche Werke, Brandenburger [until 1991 Berliner] Ausgabe, ed. R. Reuß and P. Staengle. Frankfurt/M and Basel: Stroemfeld/Roter Stern 1988-.

A. Boeckh (1877), Encyclopädie und Methodologie der Philologischen Wissenschaften, ed. E. Bratuschek. Leipzig.

B. Böhm (1929), Sokrates im 18. Jahrhundert: Studien zum Werdegang des modernen Persönlichkeits-Bewusstseins. Leipzig: Quelle \& Meier.

R. Borgards (2005), ““Allerneuester Erziehungsplan”: Ein Beitrag Heinrich von Kleists zur Experimentalkultur um 1800 (Literatur, Physik), in M. Krause and N. Pethes (eds), Literarische Experimentalkulturen: Poetologien des Experiments im 19. Jahrhundert. Würzburg: Königshausen \& Neumann, pp. 75-101. 
G. Blamberger (2011), Heinrich von Kleist: Biographie. Frankfurt: Fischer.

H. Brown (1998), Heinrich von Kleist: the Ambiguity of Art and the Necessity of Form. Oxford: Oxford University Press.

G. Figal (2014), 'Figuren der Unabsichtlichkeit. Heinrich von Kleists Über das Marionettentheater wiedergelesen’, in Frick, Heinrich von Kleist, pp. 87-100

L. Földényi (1999), Heinrich von Kleist: Im Netz der Wörter. Munich: Matthes \& Seitz.

L. Földényi (2011), 'Die Inszenierung des Erotischen. Heinrich von Kleist, 'Über das Marionettentheater’’, Kleist-Jahrbuch, pp. 135-147.

S. Franzel (2014), 'Romantic Encyclopedics and the Lecture Form: Schelling, A.W. Schlegel, A. von Humboldt’, European Romantic Review 25.3, pp. 347-356.

W. Frick (1997), 'Kleist’s “Wissenschaft”. Kleiner Versuch über die Gedankenakrobatik eines Un-Disziplinierten’, Kleist-Jahrbuch, pp. 207-240.

W. Frick (ed) (2014), Heinrich von Kleist: Neue Ansichten eines rebellischen Klassikers. Freiburg i.B.: Rombach

H.U. Gumbrecht and F. Knüpling (eds) (2014), Kleist revisited. Munich: Fink.

C. Güthenke (2010), ‘The Potter’s Daughter’s Sons. German Classical Scholarship and the Language of Love circa 1800', Representations 109.1, pp. 122-147.

G. Heinrich (1983). 'Die Geisteswissenschaften an der Universität Frankfurt/O. um 1800. Bemerkungen zu Studienangebot und Gelehrtenbestand an der Hochschule Heinrich von Kleists vor ihrer Auflösung', Kleist-Jahrbuch, pp. 71-97.

J. Hibberd (2001), ‘Kleist’s ‘Marionettentheater' - ‘ein politisch Lied'?’, Oxford German Studies 30.1, pp. 80-106.

R. Loch (2003), Kleist: Eine Biographie. Göttingen: Wallstein.

C. Lubkoll and G. Oesterle (eds) (2011), Gewagte Expermiente und kühne Konstellationen: Kleists Werk zwischen Klassizismus und Romantik. Würzburg: Königshausen und Neumann.

Y. Lü, A. Stephens et al (eds) (2012), Wissensfiguren im Werk Heinrich von Kleists. Freiburg i.B.: Rombach.

P. de Man (1984), 'Aesthetic Formalization: Kleist’s Über das Marionettentheater', The Rhetoric of Romanticism. New York: Columbia University Press, pp. 263-290.

D. Martin (2014), 'Beschreibung eines 'Kampfes' - Kleist und die Weimarer Klassik’, in Frick, Heinrich von Kleist, pp. 367-390. 
D. Martyn (2004), 'Gewalt der Rede, Gewalt des Verstehens: Schleiermacher, Meier, Kleist', in S. Heinen and H. Nehr (eds), Krisen des Verstehens um 1800. Würzburg: Königshausen \& Neumann, pp. 75-90.

M. Nussbaum (1979), 'The Speech of Alcibiades: a Reading of Plato’s Symposium', Philosophy and Literature 3.2, pp. 131-172.

D. Orrells (2011), Classical Culture and Modern Masculinity. Oxford: Oxford University Press.

T. Pavel (1996), L'Art de l'éloignement: Essai sur l'imagination classique. Paris:

Gallimard.

T. Power (2011), 'Cyberchorus: Pindar's K $\eta \lambda \eta \delta o v \varepsilon \varsigma$ and the aura of the artificial', in Archaic and Classical Choral Song: Performance, Politics and Dissemination, ed. L. Athanassaki and E. Bowie. Berlin: de Gruyter, pp. 67-114.

J.A. Rushing Jr. (1988), 'The Limitations of the Fencing Bear: Kleist’s “Über das Marionettentheater” as Ironic Fiction’, The German Quarterly 61.4, pp. 528-539.

F. Schleiermacher, P. M. Steiner, et al. (1996), Über die Philosophie Platons. Geschichte der Philosophie; Vorlesungen über Sokrates und Platon (zwischen 1819 und 1823); Die Einleitungen zur Übersetzung des Platon (1804-1828). Hamburg, Meiner.

H. Schmidt (1978), Heinrich von Kleist: Naturwissenschaft als Dichtungsprinzip. Bern/Stuttgart: P. Haupt.

H. Sembdner (ed) (1996 [1984]), Heinrich von Kleists Lebensspuren: Dokumente und Berichte der Zeitgenossen. Munich: Hanser.

F. Sheffield (2006), Plato's Symposium: the Ethics of Desire. Oxford: Oxford University Press.

J. Smith (1995), 'Dialogic Midwifery in Kleist's Marquise von O. and the Hermeneutics of Telling the Untold in Kant and Plato', PMLA 100.2, pp. 203-219.

J. Söffner (2014), 'Lüge - Finte - Fiktion. Die zwei Gesten des fechtenden Bären in Kleists Marionettentheater', in Gumbrecht and Knüpling, Kleist revisited, pp. 135146.

B. Specht (2010), Physik als Kunst: Die Poetisierung der Elektrizität um 1800. Berlin: de Gruyter.

D. Steiner (1996), 'For love of a statue: a reading of Plato’s Symposium 215A-B', Ramus 25, pp. 89-111.

W. Vosskamp (2014), 'Lernprozesse mit tödlichem Ausgang. Kleists antiklassische Erzählmodelle’, in Gumbrecht and Knüpling, Kleist revisited, pp. 79-94. 
A. Weigel (1988), 'Der Schauspieler als Maschinist. Heinrich von Kleists Über das Marionettentheater und das "Königliche Nationaltheater", in D. Grathoff (ed),

Heinrich von Kleist: Studien zu Werk und Wirkung. Opladen: Westdeutscher Verlag, pp. 263-280.

B. Zimmermann (2014), 'Antiketransformationen in Heinrich von Kleists Dramen', in Frick, Heinrich von Kleist, pp. 321-343. 